\title{
Higher Ramie mosaic virus transmission efficiency by females than by males of Bemisia tabaci MED
}

\author{
Jing Peng ${ }^{1,2}$, Gang Xie ${ }^{2}$, Songbai Zhang ${ }^{2}$, Limin Zheng ${ }^{2}$, Yang Gao ${ }^{2}$, Zhuo Zhang ${ }^{2}$, Luyun Luo ${ }^{2}$, \\ Pin $\mathrm{Su}^{2}$, Dongwei Wang ${ }^{2}$, Yong Liu ${ }^{2}$, Liangying Dai ${ }^{1 *}$ \& Deyong Zhang ${ }^{1,2^{*}}$ \\ Begomoviruses can modify their transmission vector, Bemisia tabaci, to benefit their spread, although \\ this may not always be the case. Here, the new begomovirus Ramie mosaic virus (RaMoV) and its vector \\ B. tabaci MED, which is dominant in China and many regions of the world, were used as a model to \\ examine direct and indirect interaction and virus transmission by $B$. tabaci MED of different sexes. No \\ significant direct or indirect effects of RaMoV were observed in B. tabaci MED females, although RaMoV \\ could shorten the life span of $B$. tabaci MED females by up to 4 days. A test of RaMoV transmission by \\ different sexes of $B$. tabaci MED showed that there was higher virus transmission efficiency by females \\ than males. Overall, RaMoV is transmitted by $B$. tabaci MED in a sex-dependent manner, and further \\ research is needed to uncover the mechanism of the difference in RaMoV transmission by different \\ sexes of B. tabaci.
}

Approximately $80 \%$ of epidemic plant viruses in the field are transmitted by insect vectors from plant to plant and spread to distantly located regions in this way ${ }^{1}$. The whitefly Bemisia tabaci (Gennadius) (Hemiptera: Aleyrodidae) is a species complex with a worldwide distribution, and at least 35 cryptic species are widely recognized based on the evidences of molecular phylogenetic data and reciprocity between genetic groups ${ }^{2}$. Of these cryptic species, two invasive species, Mediterranean (MED) and Middle East-Asia Minor 1 (MEAM1), severely harm plants by direct feeding and by indirect transmitting plant viruses ${ }^{3}$.

Plant viruses are not passively transmitted by their vectors; instead, they can produce direct and indirect effects on the vectors to modify their behaviour, life span and fitness to benefit their own transmission. Tomato yellow leaf curl virus (TYLCV) could directly mediate the behaviours of its vector, whitefly, including settling, probing and feeding, to enhance its transmission efficiency $y^{4,5}$. In the case of a plant virus indirectly affecting its vector, the fecundity, longevity and population density of whiteflies increased when feeding on Tomato yellow leaf curl virus (TYLCV)-infected tobacco plants ${ }^{6-9}$.

In addition to the direct and indirect mutual relationships of plant viruses and their vectors, plant virus transmission efficiency by whitefly is relatively different depending on sex. Compared with males of B. tabaci MEAM1, females possessed higher TYLCV transmission efficiency on tomato plants ${ }^{10}$. A similar sex-based difference in transmission efficiency was also found in B. tabaci $\mathrm{MED}^{11}$.

The capacity of vectors to acquire, retain, and transmit plant viruses is critical information for inferring plant virus epidemiolog $\mathrm{y}^{12}$. Although the characteristics of acquisition, retention and transmission of several plant viruses in the genus Begomovirus by $B$. tabaci have been well documented ${ }^{11,13-15}$, the detailed characteristics of the begomoviruses transmitted by $B$. tabaci still require additional study to understand the outbreaks of Begomovirus in the world.

Ramie mosaic virus (RaMoV) is a new bipartite begomovirus that was documented from infected Boehmeria leiophylla ${ }^{16,17}$. Plant viruses in the genus Begomovirus are important pathogens in the tropical and sub-tropical regions of the world, are exclusively transmitted by whitefly in a persistent-circulative mode ${ }^{18}$ and severely

${ }^{1}$ Plant Protection college, Hunan Agricultural University, No 1 Nongda Road, Furong District, Changsha, 410120, Hunan province, P.R. China. ${ }^{2}$ Hunan Plant Protection Institute, No 726 Second Yuanda Road, Furong District, Changsha, 410125, Hunan Province, P.R. China. *email: daily@hunau.net; dyzhang73@hotmail.com 


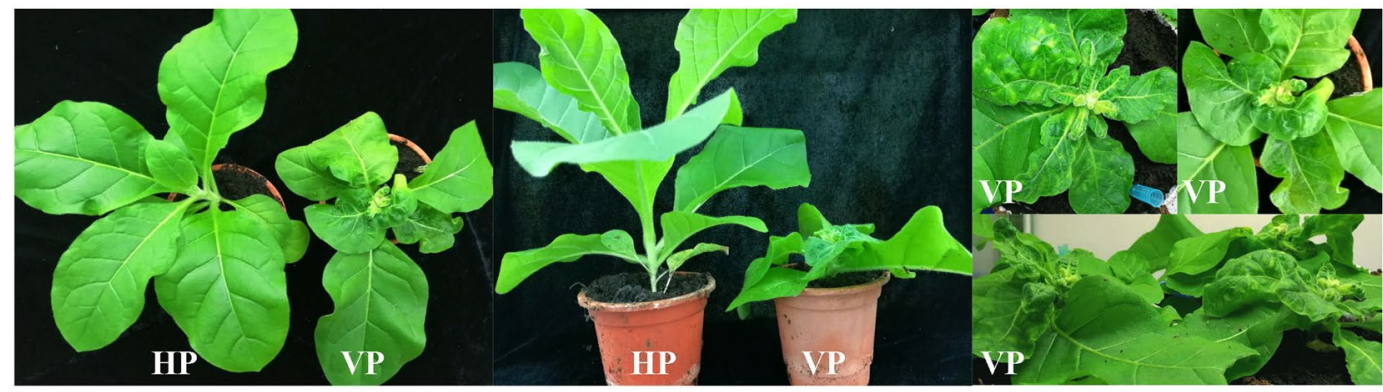

Figure 1. Symptoms of RaMoV-infected (VP) tobacco plants (10 dpi).
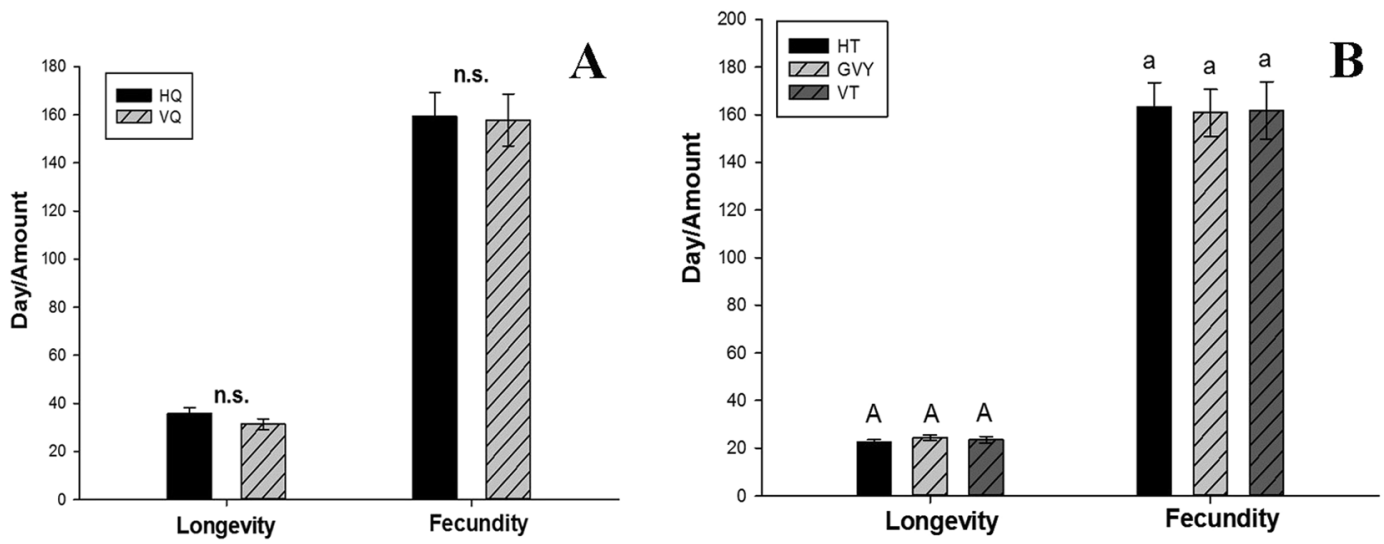

Figure 2. Direct and indirect effects of RaMoV on longevity and fecundity of $B$. tabaci MED. (A) Direct effects on B. tabaci MED by RaMoV; HQ: non-viruliferous B. tabaci MED; VQ: viruliferous B. tabaci MED; (B) Indirect effects on B. tabaci MED by RaMoV; HT: healthy tobacco; GVY: tobacco inoculated with Agrobacterium tumefaciens without RaMoV plasmid; VT: RaMoV-infected tobacco.

damage a wide range of economic crops, such as tomato, pepper and tobacco ${ }^{19}$. It is rational to deduce that RaMoV would be a potential threat to important crops.

In recent years, B. tabaci MED has progressively become a dominant species in China ${ }^{20-23}$; thus, in this study, direct and indirect effects were examined using the RaMoV and B. tabaci MED model. In addition, the acquisition, retention and transmission of RaMoV by the different sexes of $B$. tabaci MED was compared. The results would scientifically evaluate the potential epidemiology of RaMoV in the field.

\section{Result}

Symptoms of RaMoV-infected tobacco plants. To determine the indirect effects of RaMoV on $B$. tabaci MED, RaMoV-infected tobacco plants were produced. Tobacco plants with 6 true leaves were inoculated with RaMoV in the 3rd leaf by Agrobacterium tumefaciens containing an infectious clone of RaMoV. At 10 dpi, compared with healthy tobacco plants, RaMoV-infected tobacco plants were severely stunted and lacked apical dominance. The new leaves of RaMoV-infected tobacco plants manifested shrivelling and mosaic symptoms (Fig. 1).

Direct and indirect effects of RaMoV on longevity and fecundity of $B$. tabaci MED. To determine the direct effects of RaMoV on females of B. tabaci MED, viruliferous and non-viruliferous females of $B$. tabaci MED fed on healthy cucumber plants, which are not natural hosts of RaMoV. As shown in Fig. 2, although the life span of the viruliferous females of $B$. tabaci MED was $4 \mathrm{~d}$ shorter than that of the non-viruliferous females of $B$. tabaci MED (31-35 d), the difference was not significant $\left(F_{1,80}=0.503, P=0.480\right)$. Figure 2 also revealed that no significant difference $\left(F_{1,80}=0.533, P=0.467\right)$ in the fecundity of females of $B$. tabaci MED was associated with RaMoV (Fig. 2A).

The indirect impacts on fecundity and longevity of females of $B$. tabaci by RaMoV were examined via three treatments with non-viruliferous females of $B$. tabaci MED on healthy tobacco plants, RaMoV-infected tobacco plants and tobacco plants inoculated with A. tumefaciens without the RaMoV plasmid. As Fig. 2 shows, the mean number of eggs $\left(F_{2,96}=0.012, P=0.988\right)$ and the longevity $\left(F_{2,96}=0.672, P=0.513\right)$ of $B$. tabaci MED females were not significantly different among the three treatments (Fig. 2B).

Acquisition of RaMoV DNA by different sexes of B. tabaci MED. The RaMoV acquisition capability of different sexes of B. tabaci MED was compared. RaMoV DNA attained maximal viral loads in both females and 


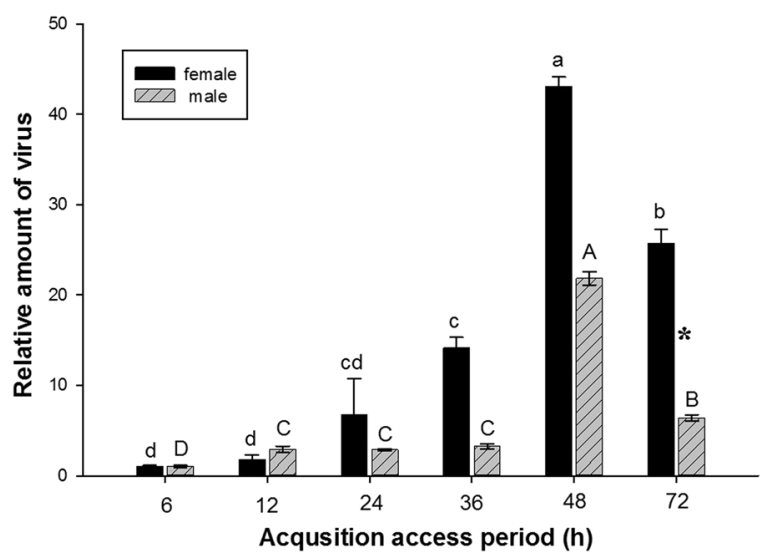

Figure 3. Acquisition of RaMoV DNA by B. tabaci MED gender.

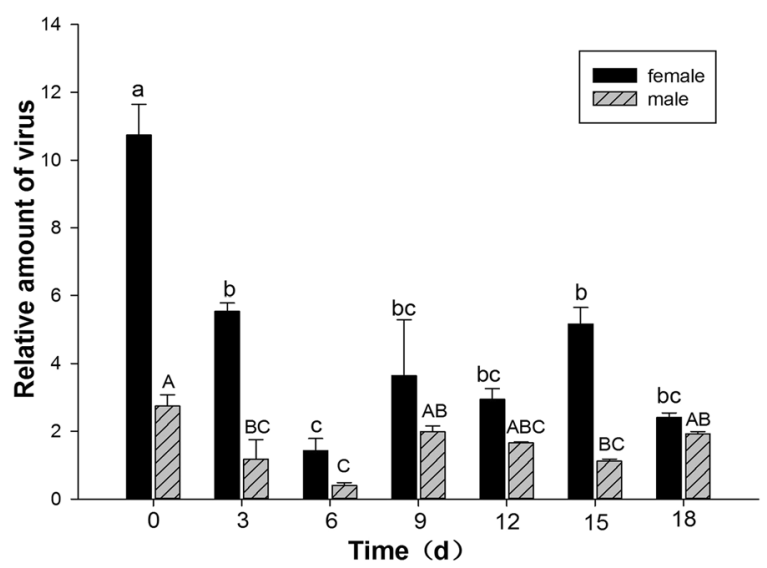

Figure 4. Retention of RaMoV DNA by different sexes of B. tabaci MED.

males of $B$. tabaci MED at $48 \mathrm{~h} \mathrm{AAP}\left(F_{\text {female 5,12 }}=78.817, P=0.002\right)\left(F_{\text {male 5,12 }}=419.587, P<0.001\right)$ and decreased after $48 \mathrm{~h}$. During the whole AAP in which $B$. tabaci acquired RaMoV, the females acquired more virus than the males; the difference was not significant in the 6-48 h AAPs $(P>0.05)$ and was significant at $72 \mathrm{~h} \mathrm{AAP}(P<0.05)$ $\left(F_{1,4}=9.259, P=0.038\right)$ (Fig. 3).

Retention of RaMoV DNA by different sexes of $B$. tabaci MED. As B. tabaci MED loads maximal RaMoV DNA at $48 \mathrm{~h}$ AAP on RaMoV-infected tobacco, the female and male populations of $B$. tabaci MED fed on RaMoV-infected tobacco for $48 \mathrm{~h}$ were then transferred to healthy cucumber plants. At day 0 , the relative amount of RaMoV DNA retained in females was greater than in males of B. tabaci. The RaMoV DNA amount plunged from day 0 to day $6\left(F_{\text {female } 6,14}=16.380, P<0.001\right)\left(F_{\text {male } 6,14}=8.030, P=0.001\right)$ and equilibrated from day 9 to day 18 in both sexes of $B$. tabaci. The retained RaMoV DNA in females was always higher than that in males of $B$. tabaci, and the difference was significant from day 12 to day $15\left(F_{12 \text { day } 1,4}=11.868, P=0.026\right)\left(F_{15 \text { day } 1,4}=11.700\right.$, $P=0.027$ ) (Fig. 4).

Transmission of RaMoV DNA by different sexes of $\boldsymbol{B}$. tabaci MED. The transmission efficiency of RaMoV by different sexes of $B$. tabaci MED was determined, and RaMoV-infected tobacco was verified by conventional PCR. As shown in Fig. 5A, the transmission efficiency of RaMoV by females was higher than by males of $B$. tabaci MED. The transmission efficiency of RaMoV by one female could reach $66.67 \%$ when fed on tobacco for $7 \mathrm{~d}$ and $75 \%$ for $14 \mathrm{~d}$, while that by two females could reach $100 \%$ for both $7 \mathrm{~d}$ and $14 \mathrm{~d}$. However, lower than $40 \%$ transmission efficiency of RaMoV to tobacco by one male of B. tabaci was observed for $7 \mathrm{~d}$ or $14 \mathrm{~d}$.

The relative amount of RaMoV DNA accumulation in tobacco leaves inoculated by $B$. tabaci of different sexes was estimated. As shown in Fig. 5B, virus DNA accumulation in tobacco leaves infested by females of $B$. tabaci MED was much higher than by males. The highest difference was up to 33.25-fold virus DNA accumulation in tobacco leaves exposed to two females compared to two males of B. tabaci MED at $7 \mathrm{~d}$. However, the virus DNA accumulation in the tobacco leaves was not significantly different among the four treatments (one male, two males, one female, two females) after $7 \mathrm{~d}\left(F_{3,26}=0.984, P=0.416\right)$ and $14 \mathrm{~d}\left(F_{3,26}=1.400, P=0.262\right)$. 

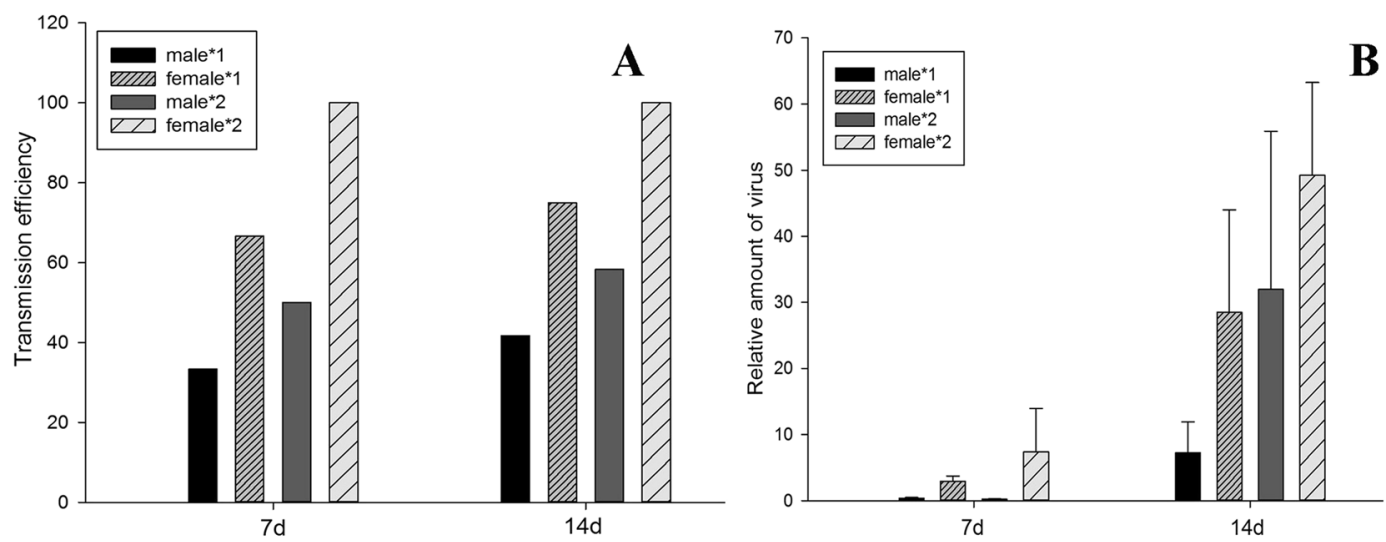

Figure 5. Transmission of RaMoV by DNA by different sexes of B. tabaci MED. (A) Transmission efficiency of RaMoV by different sexes of B. tabaci; (B) Relative amount of RaMoV DNA in tobacco leaves transmitted by different sexes of $B$. tabaci.

\section{Discussion}

It is well known that plant viruses have co-evolved with their transmission vectors and benefited via enhanced virus transmission ${ }^{4,24}$. Nevertheless, distinct effects of certain plant viruses on their vectors exist, and such interactions are ambiguous ${ }^{25}$.

This study revealed, using a new bipartite begomovirus, RaMoV, and its vector, B. tabaci MED, as a model, that there is no significant direct or indirect effect of RaMoV on females of B. tabaci MED (Fig. 2). This result is reminiscent of another bipartite begomovirus, Tomato mottle virus (ToMoV), which also had no significant effect on the fertility and longevity of its whitefly vector ${ }^{26}$. However, the begomovirus Tomato yellow leaf curl china virus (TYLCCNV) could significantly decrease the fertility and longevity of females of $B$. tabaci ${ }^{6}$. The direct and indirect effects of RaMoV and its vector, females of $B$. tabaci MED, together with a previous study, reconfirmed the disparate interactions of plant viruses and their vectors.

Our data show that both females and males of $B$. tabaci are able to acquire, retain and transmit RaMoV, and the ability of females to acquire and retain the RaMoV DNA was significantly higher than that of males (Figs. 3, 4). This indicates that females could transmit more RaMoV DNA to host plants than males of $B$. tabaci MED, and the transmission efficiency results (Fig. 5) also verified this tendency. This result was consistent with those achieved for other begomoviruses and their vectors: that $B$. tabaci transmits begomovirus in a sex-dependent manner, and higher transmission efficiency achieved by females ${ }^{11,27,28}$. Females acquired and retained much more RaMoV DNA than males of $B$. tabaci MED, which was possibly dependent on the feeding capacity of females being higher than that of males of $B$. tabaci ${ }^{4}$; however, the relationship between $B$. tabaci feeding behaviour and its virus acquisition ability still needs to be confirmed.

In conclusion, this study showed that a new begomovirus, RaMoV, has no significant direct or indirect effect on its vector, B. tabaci MED, that RaMoV transmitted by $B$. tabaci MED in a sex-dependent manner, and that higher transmission efficiency is shown by females. Further research is needed to uncover the mechanism of the difference in transmission of RaMoV by $B$. tabaci of different sexes.

\section{Material and Methods}

Insects, plants and RaMoV clone. Tobacco (Nicotiana tabacum cv. Samsun NN) and cucumber (Cucumis sativus L. cv. ChangChunMiChi) were grown in a potting mix in $1.5 \mathrm{~L}$ pots (one plant/pot) at $26 \pm 2{ }^{\circ} \mathrm{C}$ under a $16 \mathrm{~h}$ light $/ 8 \mathrm{~h}$ dark day cycle. The tobacco plants at the 6-8 true-leaf stage was inoculated with virus by $A$. tumefaciens GV3101 containing a RaMoV plasmid, which was constructed and stored in our laboratory.

The B. tabaci MED population was maintained in whitefly-proof screen cages at $26 \pm 2{ }^{\circ} \mathrm{C}$ with a $16 \mathrm{~h} \mathrm{light} / 8 \mathrm{~h}$ dark day cycle. The purity of the MED population was monitored by CAPS (cleavage amplified polymorphic sequence) of $m t C O I$ (mitochondrial cytochrome oxidase I genes) with the restriction endonuclease VspI ${ }^{29}$.

Fecundity and longevity of whiteflies. The direct effects of RaMoV on the fecundity and longevity of females of $B$. tabaci were examined by clip-caging viruliferous or non-viruliferous insects with leaves of healthy cucumber. Viruliferous insects were generated from new-born female adults fed on the leaves of RaMoV-infected tobacco for $48 \mathrm{~h}$ by clip-caging and then transferred to leaves of healthy cucumber. Non-viruliferous insects were generated on healthy tobacco of the same growth stage. A set of 40 female $B$. tabaci individuals in each experimental group was used.

The indirect impacts of RaMoV on the fecundity and longevity of female B. tabaci MED were examined by clip-caging newly emerged non-viruliferous $B$. tabaci from healthy cucumber plants with healthy tobacco, RaMoV-infected tobacco or Agrobacterium-infected tobacco. The clip-cages were attached to the third to sixth leaf of each tobacco plant. Each newly emerged non-viruliferous B. tabaci MED adult female was clip-caged to ovipositor on tobacco for five days (one clip-cage per tobacco plant) until death.

The eggs deposited on cucumber/tobacco leaves were counted and marked with an insect needle under a stereomicroscope (Leica, DFC450, Leica Microsystes, Germany). The adults and the clip-cages were then moved 
to new leaves. Every female was checked every 5 days until death, and their longevity was calculated to determine the effects of RaMoV for each replicate.

Acquisition, retention and transmission of RaMoV by different sexes of $B$. tabaci MED. To test the acquisition of RaMoV by different sexes of $B$. tabaci MED, approximately 300 newly emerged (0-24h) non-viruliferous female or male adult individuals were taken from their respective cultures and transferred to feed on RaMoV-infected tobacco plants enclosed in a clip-cage. To ensure that the insects remained healthy, the transfer process of insects from leaf to leaf was performed gently. Following adult transfer, we randomly collected 20 adults from the leaves of the two plants at the end of 6 designated acquisition access periods (AAPs; $6 \mathrm{~h}, 12 \mathrm{~h}$, $24 \mathrm{~h}, 36 \mathrm{~h}, 48 \mathrm{~h}, 72 \mathrm{~h}$ ). The collected adults were stored at $-20^{\circ} \mathrm{C}$ and later assayed individually for detectable RaMoV DNA by qPCR.

To evaluate the retention of RaMoV by $B$. tabaci MED on the basis of sex, approximately 300 newly emerged (0-24h) non-viruliferous female or male adults were transferred to feed on two RaMoV-infected tobacco plants enclosed in an insect-proof cage for $48 \mathrm{~h}$ AAP to obtain $100 \%$ viruliferous $B$. tabaci MED. Then, the viruliferous adult female or male $B$. tabaci MED were collected and released to feed on a healthy cucumber plant, a non-host of RaMoV. After the initial release, a group of 20 live adults were collected at 0, 3, 6, 9, 12 and $15 \mathrm{~d}$. The insect samples collected were stored at $-20^{\circ} \mathrm{C}$, and later, RaMoV DNA was detected by qPCR.

To estimate the transmission of RaMoV to tobacco plants by $B$. tabaci MED on the basis of sex, viruliferous adults generated as above were collected and inoculated in groups of 1 and 2 on the second leaf from the bottom of an uninfected tobacco plant at the three-true-leaf stage using a clip-cage for a $48 \mathrm{~h}$ inoculation access period. After $7 \mathrm{~d}$ and $14 \mathrm{~d}$, the tobacco plants in each of the treatments were examined for virus infection by RaMoV symptoms and conventional PCR, and the RaMoV DNA accumulation in tobacco leaves was quantified by qPCR.

Viral DNA detection in B. tabaci and tobacco. Total genomic DNA of B. tabaci and tobacco was extracted by the CTAB method ${ }^{30}$. For specific detection of RaMoV in B. tabaci and tobacco, the specific primer (CP-F: 5'-TATCGCAAGCCCAAGATG-3' and CP-R, 5'-3': GACCTCCAGTAACAGTTGACG) of the partial CP gene fragment of RaMoV (774bp) (GenBank No. NC_010791.1) was used to conduct conventional PCR. The reaction mixture $(20 \mu \mathrm{L})$ contained $10 \times$ PCR buffer $\left(\right.$ no $\left.\mathrm{Mg}^{2+}\right) 2 \mu \mathrm{L}, \mathrm{MgCl}_{2}(50 \mathrm{mM}) 0.8 \mu \mathrm{L}, \mathrm{dNTPs}(10 \mathrm{mM})$ $0.2 \mu \mathrm{L}$, primers $(10 \mathrm{mM}) 0.2 \mathrm{uL}$ each, enzyme mix $(1000 \mathrm{U}) 0.5 \mu \mathrm{L}$, RNA inhibitor $0.1 \mu \mathrm{L}, \mathrm{ddH}_{2} \mathrm{O} 16 \mu \mathrm{L}$. The following cycling conditions were used: initial denaturation at $94^{\circ} \mathrm{C}$ for $2 \mathrm{~min} ; 35$ cycles of $94^{\circ} \mathrm{C}$ for $30 \mathrm{~s}, 55^{\circ} \mathrm{C}$ for $1.5 \mathrm{~min}$, and $72^{\circ} \mathrm{C}$ for $1.5 \mathrm{~min}$; and a final extension step at $72^{\circ} \mathrm{C}$ for $10 \mathrm{~min}$. The PCR products were sequenced to ensure the accuracy of the insertion sequence.

For quantification of RaMoV DNA in insects and tobacco, qPCR was conducted as in a previous study ${ }^{13}$ with minor modifications. The specific primers (qPCR-F: GGTTCTGCGTAAAGTCCG and qPCR-R: TTGACCTCCAGTAACAGTTGAC) for the partial CP gene fragment of RaMoV (200 bp) (GenBank No. NC_010791.1) were used. qPCR reactions were carried out in a 96-well optical plate in an Analytik Jena AG PCR instrument, and the accompanying software was used for GPCR data normalization and quantification. Amplifications for RaMoV were performed with $2 \times$ TransStar Green qPCR Super Mix UDG (Trans Gene Biotech (Beijing), Co., Ltd). For each sample, three replicates were performed for each of the three biologically independent experiments. The relative gene expression of the RaMoV CP gene was calculated using the $2^{-\triangle \triangle \mathrm{Ct}} \operatorname{method}^{31}$. $\beta$-actin from $B$. tabaci $^{13}$ and EF- $1 \mathrm{a}^{32}$ from tobacco were used as reference genes to normalize the gene expression level.

Data analysis. Statistical analyses were performed with SPSS (version 22.0; SPSS Inc., Chicago, IL, USA). Means were compared by the least significant difference (LSD) test at $\mathrm{P}=0.05$.

Received: 16 August 2019; Accepted: 27 December 2019;

Published online: 16 January 2020

\section{References}

1. Fereres, A. \& Moreno, A. Behavioural aspects influencing plant virus transmission by homopteran insects. Virus Res. 141, 158-168 (2009).

2. De Barro, P. J., Liu, S. S., Boykin, L. M. \& Dinsdale, A. B. Bemisia tabaci: a statement of species status. Annu Rev Entomol. 56, 1-19 (2011).

3. Naranjo, S. E., Castle, S. J., De Barro, P. J. \& Liu, S. S. Population dynamics, demography, dispersal and spread of Bemisia tabaci. In: Bemisia: Bionomics and Management of a Global Pest. Springer, Netherlands. (eds. P. A. Stansly \& S. E. Naranjo), Chapter 6, 185-226 (2010).

4. Moreno-Delafuente, A., Garzo, E., Moreno, A. \& Fereres, A. A plant virus manipulates the behavior of its whitefly vector to enhance its transmission efficiency and spread. PLoS One. 8(4), e61543 (2013).

5. Liu, B. M. et al. Multiple forms of vector Manipulation by a Plant-infecting virus: Bemisia tabaci and Tomato Leaf Crul Virus. J Virol. 87(9), 4929-4937 (2013).

6. Jiu, M. et al. Vector-virus mutualism accelerates population increase of an invasive whitefly. PLoS One. 2(1), e182 (2007).

7. Pan, H. P. et al. Differential effects of an exotic plant virus on its two closely related vectors. Sci Rep. 3, 2230 (2013).

8. Su, Q. et al. Manipulation of host quality and defense by a plant virus improves performance of whitefly vectors. J Econ Entomol. 108(1), 11-19(2015).

9. Su, Q. et al. Tomato yellow leaf curl virus differentially influences plant defense responses to a vector and a non-vector herbivore. Plant cell environ. 39(3), 597-607 (2016).

10. Xie, W., Xu, Y. X., Jiao, X. G. \& Zhang, Y. J. High efficient of females of B-type Bemisia tabaci as males in transmitting the whiteflyborne tomato yellow leaf curl virus to tomato plant with q-PCR method confirmation. Commun Integr Biol. 5(6), 543-545 (2012).

11. Ning, W. X. et al. Transmission of Tomato yellow leaf curl virus by Bemisia tabaci as affected by whitefly sex and biotype. Sci Rep. $\mathbf{5}$, 10744 (2015)

12. Polston, J. E., Al-Musa, A., Perring, T. M. \& Dodds, J. A. Association of the nucleic acid of squash leaf curl geminivirus with the whitefly Bemisia tabaci. Phytopathol. 80(9), 850-856 (1990). 
13. Guo, T. et al. Comparison of transmission of Papaya leaf curl China virus among four cryptic species of the whitefly Bemisia tabaci complex. Sci Rep. 5, 15432 (2015).

14. Su, Q. et al. Insect symbiont facilitates vector acquisition, retention, and transmission of plant virus. Sci Rep. 3, 1367 (2013).

15. Pan, H. P. et al. Rapid spread of Tomato yellow leaf curl virus in china is aided differentially by two invasive whiteflies. PLoS One. 7(4), e34817 (2012).

16. Li, J., Zhang, X. Y. \& Qian, Y. J. Molecular characterization of Ramie mosaic virus isolates detected in Jiangsu and Zhejiang province, China. Acta Virolog. 54(3), 225-228 (2010).

17. Zhao, L. L., Zhong, J., Zhang, X. Y., Ding, M. \& Zhang, Z. K. Complete genome sequence of a new bipartite begomovirus infecting Boehmeria leiophylla in China. Arch Virol. 163(7), 1989-1992 (2018)

18. Navas-Castillo, J., Fiallo-Olivé, E. \& Sánchez-Campos, S. Emerging virus diseases transmitted by whiteflies. Annu Rev Phytopathol. 49, 219-248 (2011).

19. Mughra, R. B., Liu, S. S. \& Zhou, X. P. Tomato yellow leaf curl virus and Tomato leaf curl Taiwan virus invade south-east coast of China. J Phytopathol. 156, 217-221 (2008).

20. Fang, Y., Wang, J., Luo, C. \& Wang, R. Lethal and sublethal effects of clothianidin on the development and reproduction of Bemisia tabaci (Hemiptera: Aleyrodidae) MED and MEAM1. J Insect Sci. 18(2), 37 (2018).

21. Xiao, N., Pan, L. L., Zhang, C. R., Shan, H. W. \& Liu, S. S. Differential tolerance capacity to unfavourable low and high temperatures between two invasive whiteflies. Sci Rep. 6, 24306 (2016).

22. Pan, H. P. et al. Insecticides promote viral outbreaks by altering herbivore competition. Ecol Appl. 25(6), 1585-1595 (2015).

23. Zheng, H. X. et al. Dynamic monitoring (B versus Q) and further resistance status of Q-tpye Bemisia babaci in china. Crop prot. 94 , 115-122 (2017).

24. Mauck, K. E., Bosque-Perez, N. A., Eigenbrode, S. D., De Moraes, C. M. \& Mescher, M. C. Transmission mechanisms shape pathogen effects on host-vector interactions: Evidence from plant viruses. Funct Ecol. 26(5), 1162-1175 (2012).

25. Mauck, K. E., De Moraes, C. M. \& Mescher, M. C. Deceptive chemical signals induced by a plant virus attract insect vectors to inferior hosts. Proc Natl Acad Sic USA 107(8), 3600-3605 (2010).

26. Mckenzie, C. L. Effect of tomato mottle virus (ToMoV) on Bemisia tabaci biotype B (Homoptera: Aleyrodidae) oviposition and adult survivorship on healthy tomato. Fla Entomol. 85(2), 367-368 (2002).

27. Ghanim, M. \& Czosnek, H. Tomato yellow leaf curl geminivirus (TYLCV-Is) is transmitted among whiteflies (Bemisia tabaci) in a sex-related manner. J Virol. 74(10), 4738-4745 (2000).

28. van de Wetering, F., van der Hoek, M., Goldbach, R. \& Peters, D. Differences in tomato spotted wilt virus vector competency between males and females of Frankliniella occidentalis. Entomol Exp Appl. 93(1), 105-112 (1999).

29. Frolich, D. R., Torres-Jerez, I., Bedford, I. D., Markham, P. G. \& Brown, J. K. A phylogeographical analysis of the Bemisia tabaci species complex based in mitochondrial DNA markers. Mol Ecol. 8(10), 1593-1602 (1999).

30. Steiner, J. J., Poklemba, C. J., Fjellstrom, R. G. \& Elliott, L. F. A rapid one-tube genomic DNA extraction process for PCR and RAPD analyses. Nucl Acid Res. 23(13), 2569-2570 (1995)

31. Livak, K. J. \& Schmittgen, T. D. Analysis of relative gene expression data using real-time quantitative PCR and the $2^{-\Delta \Delta C t}$ method. Methods. 25(4), 402-408 (2001).

32. Klie, M. \& Debener, T. Identification of superior reference genes for data normalisation of expression studies via quantitative PCR in hybrid roses (Rosa hybrida). BMC Res Notes. 4, 518 (2011).

\section{Acknowledgements}

This work was supported by the National Natural Science Foundation of China $(31601609,31801708)$ and the National Natural Science Foundation of Hunan Province (2018JJ3307). China Agriculture Research System (CARS-16-E 17), Exceptional Talent of Ministry of Agriculture and Rural Affairs of the People's Republic of China (13190200).

\section{Author contributions}

J.P. and D.Y.Z. conceived and designed the experiments. J.P., G.X., L.M.Z., Z.Z., L.Y.L., Y.G., P.S. and D.W.W. performed the experiments, analyzed the data, contributed reagents and materials. J.P., S.B. Z., Y.L., L.Y.D. and D.Y.Z. wrote the paper. All authors reviewed the manuscript and approved the publication.

\section{Competing interests}

The authors declare no competing interests.

\section{Additional information}

Correspondence and requests for materials should be addressed to L.D. or D.Z.

Reprints and permissions information is available at www.nature.com/reprints.

Publisher's note Springer Nature remains neutral with regard to jurisdictional claims in published maps and institutional affiliations.

Open Access This article is licensed under a Creative Commons Attribution 4.0 International License, which permits use, sharing, adaptation, distribution and reproduction in any medium or format, as long as you give appropriate credit to the original author(s) and the source, provide a link to the Creative Commons license, and indicate if changes were made. The images or other third party material in this article are included in the article's Creative Commons license, unless indicated otherwise in a credit line to the material. If material is not included in the article's Creative Commons license and your intended use is not permitted by statutory regulation or exceeds the permitted use, you will need to obtain permission directly from the copyright holder. To view a copy of this license, visit http://creativecommons.org/licenses/by/4.0/.

(C) The Author(s) 2020 